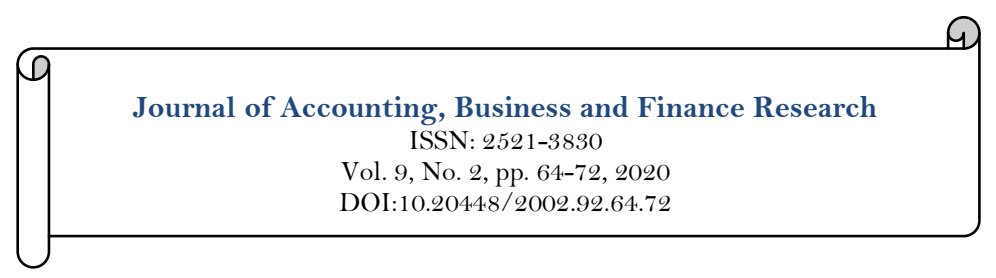

\title{
CSR and Firm Performance Nexus in UK: Empirical Evidence of Manufacturing Sector
}

\author{
Daniel Limones \\ University of Leeds, England. \\ Email:Daniel.Li111@yahoo.com
}

\begin{tabular}{|c|c|}
\hline Abstract & \\
\hline $\begin{array}{l}\text { The study aims to determine the impact of CSR on the firm performance in } \\
\text { the context of manufacturing of UK. The study focuses on adopting the } \\
\text { quantitative design of research, while the instrument used for the purpose of } \\
\text { gathering the respondents is survey questionnaire. The data collected from } \\
\text { 3O5 respondents working in the manufacturing sector of UK. The Smart } \\
\text { PLS method is used for analysis. The data examines by using the } \\
\text { measurement and path assessment model. The results indicate that there is a } \\
\text { significant and positive impact of the corporate social responsibility on the } \\
\text { firm performance of companies operating in manufacturing sector of UK. } \\
\text { The study is limited to the manufacturing sector only that is operating } \\
\text { within UK. Nevertheless, the research has various implications for the } \\
\text { manufacturing sector of UK, and its managers and workers. }\end{array}$ & $\begin{array}{l}\text { Keywords: } \\
\text { Corporate social responsibility } \\
\text { (CSR) } \\
\text { Firm performance } \\
\text { Manufacturing sector } \\
\text { UK. } \\
\text { Licensed: } \\
\text { This work is licensed under a } \\
\text { Creative Commons Attribution } 4.0 \\
\text { License. } \\
\text { Publisher: } \\
\text { Scientific Publishing Institute } \\
\text { Received: } 23 \text { April } 2020 \\
\text { Revised: } 1 \text { June } 2020 \\
\text { Accepted: } 12 \text { June } 2020 \\
\text { Published: } 29 \text { June } 2020\end{array}$ \\
\hline
\end{tabular}

Funding: This study received no specific financial support.

Competing Interests: The author declares that there are no conflicts of interests regarding the publication of this paper.

\section{Introduction}

In the current contemporary marketplace, corporate social responsibility (CSR) has emerged as an important field of study. The empirical evidence pertaining to CSR indicates that involvement of companies in CSR activities is associated with improved market image and company performance (Dabas, 2011). There are studies that have suggested that CSR activities tend to influence customer satisfaction, brand image, and favourable attitudes towards the company in a positive manner. These relational benefits tend to further impact the financial performance of the company in a positive manner (Galant \& Cadez, 2017). Generally, CSR is referred to the strategies that are developed and implemented by companies that affect society and environment in a socially ethical manner. Other than profit generation, companies are now working towards creating sustainable benefits for the current stakeholders as well as the future society (Maqbool \& Zameer, 2018). Over the time, CSR has become a part of the overall organizational strategy that addresses the social and environmental impact of the business operations. In the UK, there has been a strong significance of the business on the economy, where the environmental factors along with society is increasingly being debated for transparency and the customers on the corporate activity on the social media (Feng, Wang, \& Kreuze, 2017; Saeidi, Sofian, Saeidi, Saeidi, \& Saaeidi, 2015). Moreover, the businesses in the UK are taking a lead when it comes to reduction in the environmental influences to improvise their operations. In addition, there are greater levels of political factors which address the climatic changes in the European countries. Currently, in the UK, $80 \%$ of the companies donated money towards communities and charities (Grantthornton, 2015). 


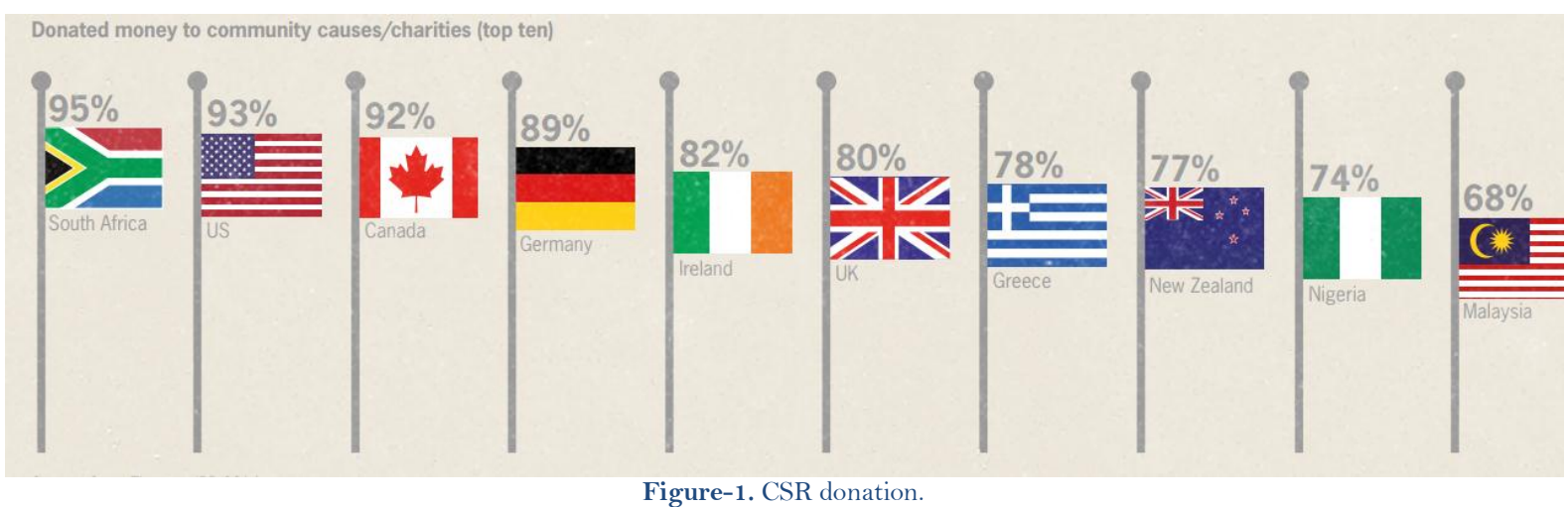

Source: Grantthornton (2015).

Based on the study of Santoso and Feliana (2014) it has been highlighted that CSR is commonly known as the renowned issue for every organisation where the stakeholders have keen interest to get awareness about the fair means of reporting in the annual reports. In addition, the interest in the CSR activities continues to increase throughout the world where different companies are focused on enhancing the voluntary activities in order to minimise the negative influences on the environment and society. However, the debates regarding the potential of CSR and its ability for creating value for the companies has interested investors and owners of the companies as it directly influences the performance of the company and also elevates the position of the company from the perspective of consumers (Sun, 2012).

In addition, there has also been a concern of many investors and company owners that they have limited capital so that they can have better access towards the loans which can make it easier for undertaking strategic decisions and investments (Choongo, 2017). Moreover, the efforts towards the increased international standards are continuously increasing because of the ethics of firms and the environment as it has now become a domestic issue which is the reason that CSR is becoming more prominent. In addition to the above statement, there has been a new directive initiated by EU directives which mandate the large corporations for increasing their reporting procedures towards the CSR-related issues as it is likely have a positive influence on their performances (Torugsa, O'Donohue, \& Hecker, 2013). However, the complexity of certain claims made by the assailants and advocates regarding CSR highlights that it creates an additional cost for the company which they have to deal with. Considering this discussion, the present research has taken into consideration the role played by CSR activities on the financial performance of manufacturing companies of UK (Lee \& Jungbae Roh, 2012). This research paper aims towards assessing the role of CSR strategy in influencing the financial performance from the perspective of the UK. In order to address the aim, the researcher has formulated the following sub-objectives:

- To study the concept of CSR in organisations from a theoretical perspective.

- To analyse the role of CSR in influencing the financial performance of manufacturing firms in the UK.

- To propose effective CSR activities that can help the companies of UK to improve their financial performance.

The research questions has been formulated as,

Q. What is the relationship between CSR and financial performance in the case of UK?

\section{Literature}

\subsection{Corporate Social Responsibility}

CSR has been an emerging area of study for the scholars and researchers focused on the sustainable development and sustainable practices within the organizations. It has emerged rapidly as field of study as the threats to the society and other stakeholders increased due to unsustainable practices that has been damaging the environment (Basuony, Elseidi, \& Mohamed, 2014). From conceptual point of view, CSR is defined by Bai and Chang (2015) as an approach and framework to address the role of business towards society, developing principles to which businesses must abide by in order to leave no negative effects on the society and environment; and also, do not strive to seek profit at any cost. CSR is a broader term that comprise acting decisively for the sustainability of the society and environment; whereas many scholars such as Choongo (2017) and Long (2015) have tried to explain the CSR as an act of engaging into the social activities to eradicate poverty and/or support backward or underprivileged members of society by means of donations, provision of free education, healthcare facilities.

In addition to, CSR also comprise of undertaking the practices and processes that assists in reducing and/or eliminating the effects on society and environment most important reduction of greenhouse gasses also known emissions that associated with the manufacturing processes, transportation and energy consumption (Kuo, Yeh, \& Yu, 2012). These forms of the sustainable practices have been made mandatory or regulations are 
being put in place to ensure manufacturing firms strictly adhere to them to reduce effects of their operations over the environment. Furthermore, the corporate social responsibility (CSR) as per Trendafilova, Babiak, and Heinze (2013) is not a legal obligation but is an ethical, moral and social responsibility to which all firms have to adhere; but due to latest developments on the emissions, and rising concerns over the global warming organizations have been advised to follow the protocol and international standards to reduce the emissions and save the planet for the generate to come.

\subsection{Firm Performance}

The economic gain or profitability achieved in positive or negative terms is said as firm's performance that may vary based on the context and industry by industry. The firm's performance may also be linked to the enhanced customers services, increased value and reputation into the market. In this regard, Saeidi et al. (2015) suggests that firms having strategic investment into CSR to enhance the local schools and improve the conditions of community can have an improved financial performance. It has been reported by Inoue and Lee (2011) and Saeidi et al. (2015) that corporate social responsibility has a positive link with the market value of the firm and financial performance of the company because the CSR positively influence the performance of the firm through customer satisfaction. Therefore, managers are suggested to have a competitive advantage into the market and this could be achieved through long-term investment into the CSR activities.

Theodoulidis, Diaz, Crotto, and Rancati (2017) stated that effects of the CSR on the firm's performance may be different for different industries and stakeholders also expect from large or small organizations to display an obligation of CSR. Because, the firms that could satisfy the stakeholders can develop strategically competitive advantage. Similarly, Stuebs and Sun (2011) have suggested that CSR is a way for the firms to enhance their reputation into the market and large firms that go under the major crises or the scandals can also use CSR as strategic investment to improve the image over a period of time. Zhu, Sun, and Leung (2014) have argued that engaging into the socially responsible activities allow firms to respond to environmental issues and engage with the various environmental agencies, non-governmental organizations and other related actors which have a positive influence on the firm's image into the market.

Similarly, as per the Ali, Rehman, Ali, Yousaf, and Zia (2010) intangible assets of the company can be considered a great source of competitive advantage for the firm and this has also been argued into the contemporary literature that intangible assets are crucial to achieve competitive advantage and employees' cooperation and collaboration are also considered an intangible resource of the company. Therefore, the loyalty of the employees and commitment could be enhanced by active engagement into the CSR because employees can have higher cooperation and collaboration that tend to increase the firm's performance. Therefore, this implies that firms being engaged into the social responsibility can have better cooperation and collaboration and employee commitments hence can enjoy improved performance.

\subsection{Empirical Study of CSR and Firm Performance}

In attempt to explain the inter-relation-ship between the CSR and firm performance, several studies have been conducted on this area of interest for instances an empirical study conducted by Mittal, Sinha, and Singh (2008) to determine interrelation between CSR and economic value added (EVA) and market value added (MVA). The authors concluded that the link among the CSR and performance in terms of market value added (MVA) and study also provided implication that if code of ethics is followed then there is weak but sufficient evidence to claim that companies that follow code of ethics could achieve higher economic value added (EVA). This implies that firms with code of ethics could enhance their profitability level means firm's performance and code of ethics is a short version of being socially responsible. Similarly, Hossein, Kamran, Mostafa, and Hossein (2012) tried to elucidate the association of CSR with economic performance of the firm; in which the author had undertaken the positive effects along with the negative effects of CSR activities on the financial performance of multiple industries including airline, restaurants and hotels. The findings of the study provided mixed results that CSR effects on the restaurants and airline industry was positive but in case of hotels industry the effects were positive but not significant.

Therefore, this implies that effect of CSR on the firm's performance could differ based on the industry and the core reason could also be disclosure of the CSR activities to the customers, general public and other all other stakeholders. Because, the study conducted Skare and Golja (2012) also studied the relationship between the CSR and financial performance and author found that firms that engage into the CSR activities enjoy better financial performance as compared to the firms that have no engagement into the CSR activities. In this regard, Saeidi et al. (2015) has explained that when a firm engage into the CSR activities then its reputation into the market increases and customers and other stakeholders perceive the firm a responsible and creates more stronger relation and customer emotional attachment with the organization. Hence, financial performance of the firm also improves at the same time. However, it is also critical that firm has appropriately disclosed the information related to the CSR and should contribute directly into the activities that have positive effect on the society and environment.

Similarly, Gautam, Singh, and Bhowmick (2016) conducted empirical investigation in India to determine how CSR disclosure lead to financial performance. The authors used regression modelling to determine effect 
of CSR disclosure on firm's performance and revealed that firm performance is positively affected by CSR disclosure and this study supports the argument of Beck, Frost, and Jones (2018) that CSR disclosure is critical to leverage the investment in CSR. It is because the engagement into the CSR tend to be highly valuable for the brand since it increases transparency. Therefore, empirically the association between the CSR has been found positive but at some industries the relation might also differ. Hence, it is evident that at some extent the investment into the CSR could be used to predict the financial performance of the firm.

Furthermore, Basuony et al. (2014) conducted a study to determine impact of corporate social responsibility on the firm's performance in case of Egypt; for the purpose of study the author conducted survey analysis and found that all dimensions of the CSR which includes; economic, legal, ethical and discretionary dimension have a positive influence over the firm's performance. Meanwhile, the study also concluded that large firms and older firms have a higher effect on the firm's performance through CSR engagement. On the other hand, another study by Alshammari (2015) aimed to investigate the effects of CSR on firm's performance while determining the role of reputation and institutional investors and authors conducted survey analysis. The study found that CSR has positive link with the firm's performance but it is also imperative that firm must maintain a reputation among the stakeholders to best benefit from the CSR activities. Meanwhile, the presence of institutional ownership also positively moderates the effect of CSR on the firm's performance. Therefore, this implies that firms with higher institutional ownership can also effectively benefit from the CSR activities.

\subsection{Theoretical Framework}

The theory of stakeholder's states that it is critical to manage and maintain relationship with the all stakeholders that are related to the firm and that could affect and can be affected by the decision of the business. The core argument of the stakeholder theory is to create value for the all those associated with the firm that may have ownership and interest within the organization (Harrison \& Wicks, 2013). The theory further explains the responsibilities of the stakeholders towards the achieving better performance and better society. It argues that all those directly related to the firm should not be considered only but rather all those that are indirect stakeholders such as customers, suppliers, general public and overall society must be considered while making decisions.

It is because the stakeholder theory argues that without support of these stakeholders the existence of the organization would not have taken place anyhow. Hence, everyone should be considered stakeholder of the business and practices and processes should be undertaken that does not undermine the interest of those groups (Greenwood \& Freeman, 2011). In contrast to the stakeholder's theory, the shareholder's theory argues that company should only care about the shareholders thus focus on the generating profit only for the shareholders to satisfy them at any cost (Smith, 2003). This provides a theorical framework from two different perspectives; where each of the theory has different implications for the shareholders of the company. As per the previous empirical findings suggests that organizations with engaging into the CSR activities are more profitable as compared to the companies that have not been engaging into the CSR activities.

\subsection{Hypothesis}

Null hypothesis: The inter-relation-ship of CSR with the firm performance is not positive and significant. Alternate Hypothesis: The inter-relation-ship of CSR with the firm performance is positive and significant.

\section{Methodology}

3.1. Research Design and Data Collection Process

This study is quantitative in nature in which the data analysis has been conducted based on numbers and figures. In this manner, the primary method of data collection has been adopted by the researcher while gathering the data using the survey questionnaire. Therefore, the closed-ended survey questionnaire was provided to the respondents in assistance to the collection of data. The questionnaire has been developed on the 5 points Likert scale ranging from strongly disagrees to strongly agree. In this regard, the data has been gathered from respondents working in the manufacturing sector of UK. The participants were approached from various platforms in which questionnaires were floated over the internet through emails for the purpose of achieving the high response rate.

\subsection{Sampling Technique and Sample Size}

Since the study has focused on determining the impact of CSR on firm performance of manufacturing therefore, the managers and employees from the manufacturing sector of UK have been considered. Therefore, the sampling strategy adopted by the researcher is purposive sampling which is the kind of non-probability sampling. This is due to the reason that the study has focused on manufacturing sector of UK and in this manner, the employees associated with the manufacturing sector of UK have been considered. Moreover, the 325 respondents were approached by the researcher those are associated with the manufacturing sector of UK and out pf which 305 respondents provided response. The response rate for this study is therefore, $93.84 \%$. 


\subsection{Data Analysis Technique}

For the purpose of analyzing the data and finding the results, the Structural Equation Modelling (SEM) has been adopted by the researcher in which the Confirmatory Factor Analysis (CFA) and path analysis has been employed. This has been due to the purpose that these techniques determine the reliability and validity of the instrument along with determining the impact of each variable. Additionally, the blindfolding has also been conducted in order to determine the predictive relevance of the model which has been theorized in the form of $Q$ square. On the other hand, the quality of model has also been recognized with the help of R-square and adjusted R-square. In this manner, the analysis has been carried out based on the SmartPLS and does not require the normality of data on the basis of PLS-SEM.

\section{Results}

4.1. Measurement Model-Partial Least Square Algorithm (PLS)

This section of the study carried the CFA analysis in order to determine the measurement model. Therefore, the reliability of each latent variable has been tested in this section. According to Avkiran and Ringle (2018) it has been suggested that the threshold for composite reliability and Cronbach Alpha is 0.6. In realization to this value, it can be determined from Table 1 that least value of Cronbach Alpha is 0.913, while the least value in terms of the composite reliability has been obtained as 0.923. Additionally, the other significant aspect of the CFA analysis is the assessment of outer loadings and according to the study of Vinzi, Chin, Henseler, and Wang (2010) the threshold for outer loadings is 0.6. Therefore, the Table 1 identified that there is no need to drop any variable i.e. the least value for outer loadings is computed to be 0.668. On the other hand, the significance of these outer loadings is also determined which shows that all the values are statistically significant. With regards to the convergent validity, the researcher has tested the readiness and association of the latent constructs. According to Jefferies and Cubric (2015) the threshold for AVE is 0.5. In this manner, Table 1 determines that the least AVE is computed to be 0.599. Therefore, this model incorporates the reflective constructs in which the indicators are caused by latent variables (Hair Jr, Hult, Ringle, \& Sarstedt, 2016).

Table-1. Reliability and convergent validity

\begin{tabular}{|c|c|c|c|c|c|}
\hline Variables & Indicators & $\begin{array}{c}\text { Outer } \\
\text { Loadings }\end{array}$ & $\begin{array}{c}\text { Cronbach's } \\
\text { Alpha } \\
\end{array}$ & $\begin{array}{l}\text { Composite } \\
\text { Reliability }\end{array}$ & $\begin{array}{c}\text { Average Variance } \\
\text { Extracted (AVE) }\end{array}$ \\
\hline \multirow[t]{8}{*}{$\begin{array}{c}\text { Corporate Social } \\
\text { Responsibility }\end{array}$} & CSR 1 & 0.668 & 0.905 & 0.923 & 0.599 \\
\hline & $\mathrm{CSR} 2$ & 0.758 & & & \\
\hline & CSR3 & 0.755 & & & \\
\hline & CSR4 & 0.763 & & & \\
\hline & CSR5 & 0.789 & & & \\
\hline & CSR6 & 0.817 & & & \\
\hline & CSR7 & 0.829 & & & \\
\hline & $\mathrm{CSR} 8$ & 0.805 & & & \\
\hline \multirow[t]{8}{*}{ Firm Performance } & $\mathrm{FP} 1$ & 0.797 & 0.913 & 0.928 & 0.620 \\
\hline & $\mathrm{FP} 2$ & 0.693 & & & \\
\hline & FP3 & 0.702 & & & \\
\hline & $\mathrm{FP}_{4}$ & 0.692 & & & \\
\hline & $\mathrm{FP5}$ & 0.838 & & & \\
\hline & $\mathrm{FP} 6$ & 0.862 & & & \\
\hline & $\mathrm{FP7}$ & 0.839 & & & \\
\hline & FP8 & 0.852 & & & \\
\hline
\end{tabular}

Along with the determination of convergent validity and reliability, it is also essential to identify the distinctiveness of the variables (Ahram, Karwowski, \& Taiar, 2018). In this manner, the HTMT ratio has been utilized for the purpose of determining that either the two variables are distinct or not while the maximum acceptable value is 0.85 which is the most conservative criterion (Kergroach, 2017). Therefore, the results presented in Table 2 determines that none of the value is exceeding the criteria of HTMT ratio which suggests that the variables can be further used for path analysis as maximum value computed to be is 0.708.

Along with determining the convergent reliability and validity, it is also necessary to determine the distinctiveness of the variables (Ahram et al., 2018). Therefore, the HTMT ratio has been used for the determination to identify that either both the variables are distinct while the acceptable value is 0.90 which is the most conservative criterion (Kergroach, 2017). In this manner, it can be determined with the help of Table 2 that none of the value exceeds the criteria of 0.9 . This depicts that the variables can further be used for the path analysis as the maximum value computed is 0.813 . 
Table-2. Discriminant Validity using HTMT Ratio.

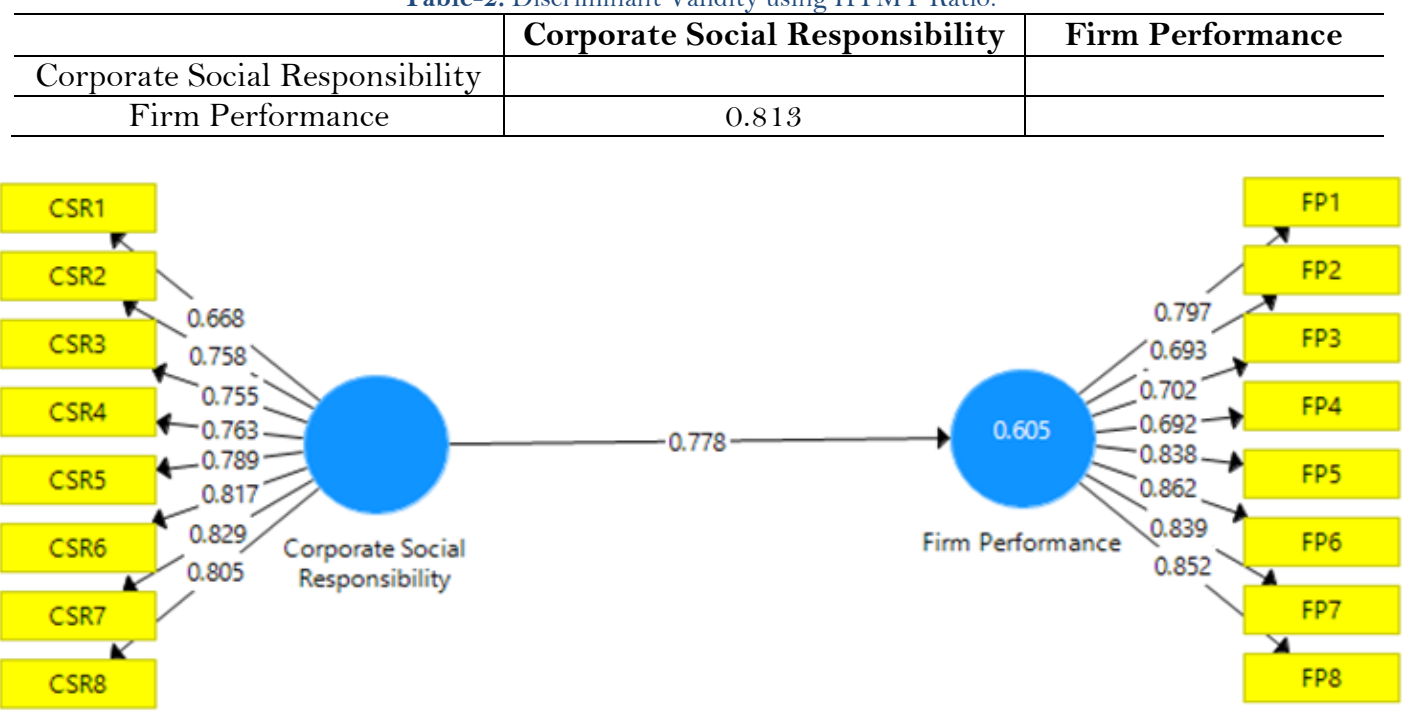

Figure-2. Measurement model.

\subsection{Path Assessment}

After assessing the measurement of the model which is used to provide the assistance regarding the determination of reliability and validity of the latent model, the SEM model has been used for the purpose of testing the significance of the hypothesised paths. In this regard, the bootstrapping has been used in order to test the significance and effect. These results can be determined from Figure 3 and Table 3. The study of Hair Jr et al. (2016) argued that the bootstrapping is regarded as the process of resampling and subsampling in order to determine the significance. On the basis of results presented in Table 3 it can be identified that the effect of CSR on the firm performance is positive and significant in the manufacturing sector of $\mathrm{UK}(\mathrm{B}=0.778$; $\mathrm{p}$-value $=0.00<0.01)$. This has been due to the reason that the $\mathrm{p}$-value or the significance value has been computed to be 0.00 which is below the level of $1 \%$. In addition to this, the effect is also computed to be positive which depicts that the increase in CSR activities will lead to the increase in the performance of the firms operating in the manufacturing sector of UK. Subsequent to the application of bootstrapping with the pvalues, the results have been presented below in Figure 3:

Table-3. Direct effect testing.

\begin{tabular}{|c|c|c|c|}
\hline Path & Path Coefficient & T Statistics & P Values \\
\hline Corporate Social Responsibility -> Firm Performance & $0.778^{* * * *}$ & 25.241 & 0.00 \\
\hline
\end{tabular}

Based on the results presented in Table 4 the total effect of corporate social responsibility on the firm performance of the manufacturing companies in UK has been found to be significant. These results can be depicted in Figure 3.

Table-4. Total effect of the study.

\begin{tabular}{|c|c|c|c|}
\hline Path & Path Coefficient & T Statistics & P Values \\
\hline Corporate Social Responsibility -> Firm Performance & $0.778^{* * * *}$ & 25.241 & 0.00 \\
\hline
\end{tabular}

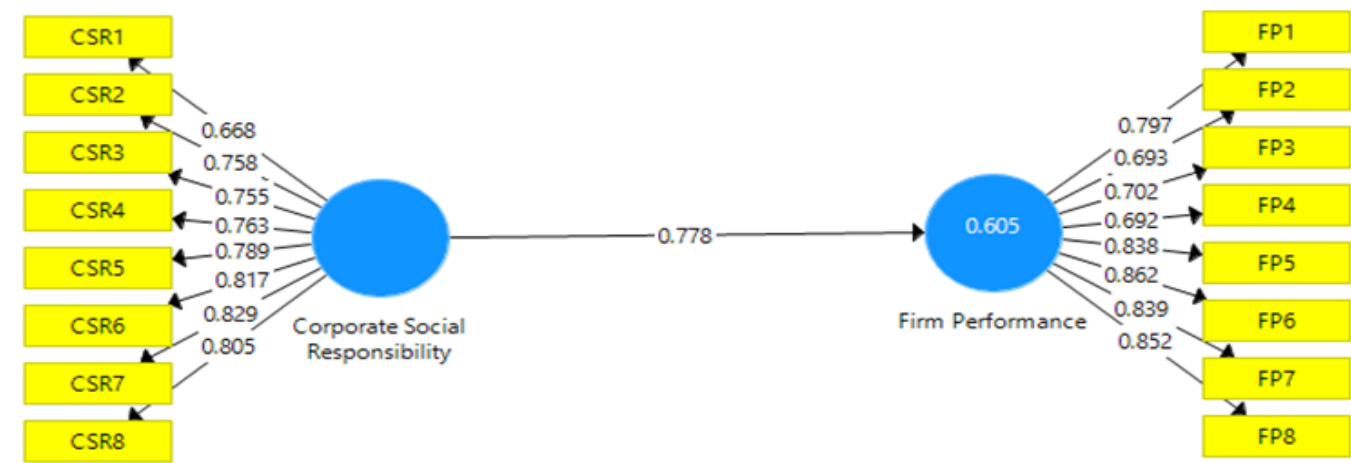

Figure-3. Bootstrapping with p-values. 


\subsection{Quality Criterion of the Model and Predictive Relevance}

After the assessment of measurement and path analysis model, it is vital and significant to evaluate the quality and predictive relevance of the model. It has been determined in the study of Miller (2014) that the Rsquared and adjusted R-squared are used to assist the evaluation of quality of the model. Pertaining to this study, the results have been well determined from Table 5 which depicts that the variance in the corporate social responsibility is explaining $60.5 \%$ of the variance in the firm performance of the companies operating in the manufacturing sector of UK. In contrast to this, the variance after the adjustment has been computed to be $60.4 \%$. Moreover, it has been argued in the study of Wong (2011) that the value of $Q$ must be above 0 for the purpose of deeming the model which has predictive relevance. Therefore, the results presented in Table 5 and Figure 4 shows that the $Q$ square value is computed to be 0.337 . This shows that the value is well above 0 . In this regard, the model of this study suggests that it holds the predictive relevance.

Table-5. Quality assessment of the model.

\begin{tabular}{c|c|c|c}
\hline & R Square & R Square Adjusted & Q Square \\
\hline Firm Performance & 0.605 & 0.604 & 0.337 \\
\hline
\end{tabular}

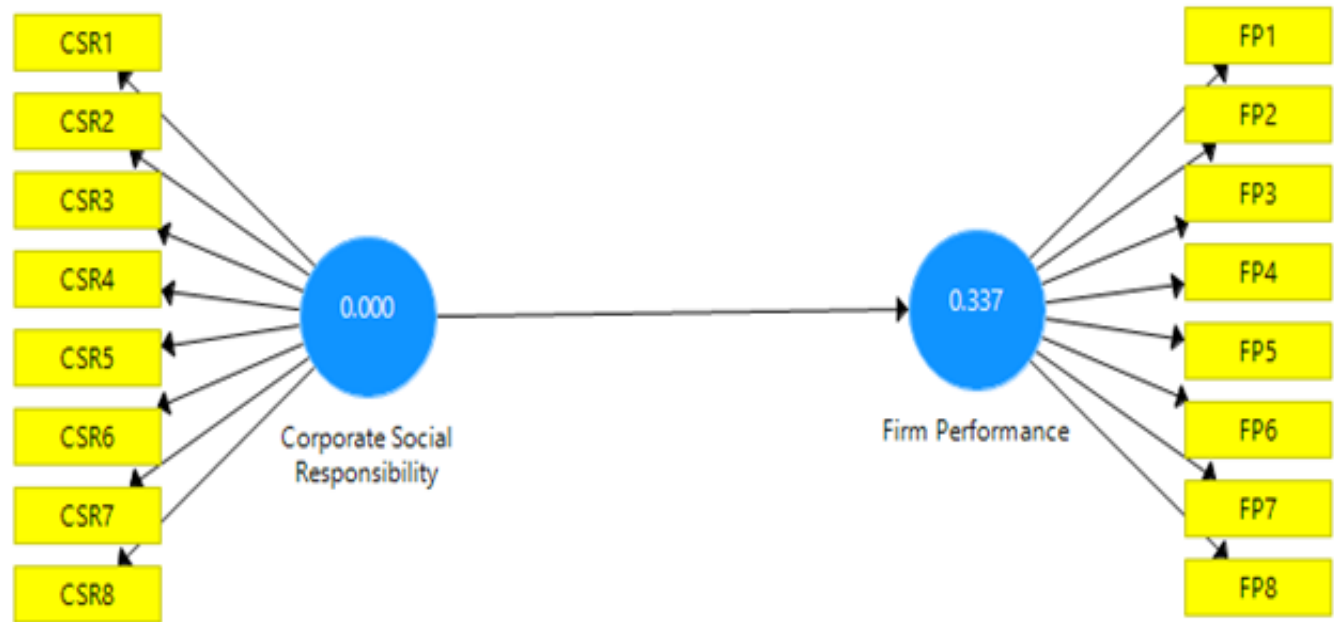

Figure-4. Blindfolding.

\subsection{Summary of Hypotheses}

The hypothesis which has been developed in the prior section of this study have now been presented and summarised in this section based on the results obtained. In this regard, it can be determined with respect to the Table 6 that the hypothesis that the inter-relation-ship of CSR with the firm performance is positive and significant has been accepted. This was due to the reason that the positive and significant impact of corporate social responsibility has been determined on the firm performance of companies operating in the manufacturing sector of UK. This hypothesis has been summarised in Table 6:

\begin{tabular}{l|l}
\multicolumn{2}{c}{ Table-6. Table of hypotheses assessment summary. } \\
\hline Propositions & Decision \\
\hline H1: The inter-relation-ship of CSR with the firm performance is positive and significant. & Accepted \\
\hline
\end{tabular}

\section{Discussion}

In order to achieve the objective of the study, the researcher has carried out the path analysis. In this manner, the overall analysis of the path assessment, it has been determined that there has been a significant impact of the corporate social responsibility on the firm performance of companies operating in the manufacturing sector of UK. This aligns with the findings of Mittal et al. (2008) in which the study concluded that there is a link among the CSR and performance in terms of market value added (MVA). Another study of Hossein et al. (2012) identified mixed results that CSR effects on the restaurants and airline industry was positive but in case of hotels industry the effects were positive but not significant. On the other hand, the results of this study also identified that there is a positive impact of the corporate social responsibility on the firm performance of companies operating in the manufacturing sector of UK. The study of Skare and Golja (2012) identified that firms that engage into the CSR activities enjoy better financial performance as compared to the firms that have no engagement into the CSR activities. Another study of Gautam et al. (2016) argued that firm performance is positively affected by CSR disclosure. Therefore, there is enough evidence to claim that there is a positive and significant impact of corporate social responsibility on the firm performance of companies operating in the manufacturing sector of UK. 


\section{Conclusion}

This study has aimed in order to determine the impact of corporate social responsibility on the firm performance of companies operating in manufacturing sector of UK. For this purpose, the quantitative method of the study has been adopted by the researcher in which the data has been gathered from the employees and managers working in the manufacturing sector of UK through survey questionnaire. The data has been analysed through measurement model and path assessment on SmartPLS. On the basis of the analysis carried out in this study, it has been determined that there is a significant and positive impact of the corporate social responsibility on the firm performance of companies operating in the manufacturing sector of UK. This depicts that the increase in corporate social responsibility will increase the firm performance. Therefore, the companies operating in the manufacturing sector of UK must adopt the CSR practices for the purpose of increasing the performance in the industry.

\section{Limitations and Future Research Direction}

This study has focused on determining the impact of corporate social responsibility on the firm performance of companies operating in manufacturing sector of UK. However, there are certain limitations of this study which must be considered by the future researchers. This study is based on manufacturing sector of UK which restricts the implication of this study results to one sector only. In this manner, it is recommended for the future researchers to include more number of industries in the study. Moreover, the study has also focused on UK which also limits the results of this study to one country. Therefore, the researchers must focus on other countries of Europe for the purpose of broadening the scope of this study.

\section{References}

Ahram, T., Karwowski, W., \& Taiar, R. (2018). Human systems engineering and design. Paper presented at the In Conference Proceedings IHSED.

Ali, I., Rehman, K. U., Ali, S. I., Yousaf, J., \& Zia, M. (2010). Corporate social responsibility influences, employee commitment and organizational performance. African Journal of Business Management, 4(13), 2796-2801.

Alshammari, M. (2015). Corporate social responsibility and firm performance: The moderating role of reputation and institutional investors. International Journal of Business and Management, 10(6), 15-28.

Avkiran, N., \& Ringle, C. (2018). Partial least squares structural equation modeling (Vol. 267): Handbook of Market Research.

Bai, X., \& Chang, J. (2015). Corporate social responsibility and firm performance: The mediating role of marketing competence and the moderating role of market environment. Asia Pacific Journal of Management, 32(2), 505530.Available at: https://doi.org/10.1007/s10490-015-9409-0.

Basuony, M. A., Elseidi, R. I., \& Mohamed, E. K. (2014). The impact of corporate social responsibility on firm performance: Evidence form a MENA country. Corporate Ownership \& Control, 12(1-9), 761-774.Available at: https://doi.org/10.22495/cocv12i1c9p1.

Beck, C., Frost, G., \& Jones, S. (2018). CSR disclosure and financial performance revisited: A cross-country analysis. Australian Journal of Management, 43(4), 517-537.Available at: https://doi.org/10.1177/0312896218771438.

Choongo, P. (2017). A longitudinal study of the impact of corporate social responsibility on firm performance in SMEs in Zambia. Sustainability, 9(8), 1-19.

Dabas, C. S. (2011). Doing well by doing good or doing smart? antecedents and outcomes of corporate social performance. Unpublished Ph.D. Dissertation, Michigan State University.

Feng, M., Wang, X., \& Kreuze, J. G. (2017). Corporate social responsibility and firm financial performance. American Journal of Business, 32(3-4), 106-133.

Galant, A., \& Cadez, S. (2017). Corporate social responsibility and financial performance relationship: A review of measurement approaches. Economic Research, 30(1), 676-693.

Gautam, R., Singh, A., \& Bhowmick, D. (2016). Demystifying relationship between corporate social responsibility (CSR) and financial performance: An Indian business perspective. Independent Journal of Management \& Production, 7(4), 1034-1062.Available at: https://doi.org/10.14807/ijmp.v7i4.443.

Grantthornton. (2015). Corporate social responsibility: beyond financials. Grantthornton.co.uk. Retrieved from: https://www.grantthornton.co.uk/globalassets/1.-member-firms/global/insights/articlepdfs/2014/ibr2014_ibr_csr_web.pdf.

Greenwood, M., \& Freeman, R. E. (2011). Ethics and HRM: The contribution of stakeholder theory. Business \& Professional Ethics Journal, 30(3-4), 269-292.Available at: https://doi.org/10.5840/bpej2011303/413.

Hair Jr, J. F., Hult, G. T. M., Ringle, C., \& Sarstedt, M. (2016). A primer on partial least squares structural equation modeling (PLS-SEM): Sage Publications.

Harrison, J. S., \& Wicks, A. C. (2013). Stakeholder theory, value, and firm performance. Business Ethics Quarterly, 23(1), 97124.

Hossein, K., Kamran, N., Mostafa, E., \& Hossein, A. (2012). Impact of corporate social responsibility activities on company performance. Interdisciplinary Journal of Contemporary Research in Business, 3(9), 583-592.

Inoue, Y., \& Lee, S. (2011). Effects of different dimensions of corporate social responsibility on corporate financial performance in tourism-related industries. Tourism Management, 32(4), 790-804.Available at: https://doi.org/10.1016/j.tourman.2010.06.019.

Jefferies, A., \& Cubric, M. (2015). ECEL2015-14th European conference on e-Learning: ECEl2015. Paper presented at the Academic Conferences and Publishing Limited.

Kergroach, S. (2017). Industry 4.0: New challenges and opportunities for the labour market. Foresight and STI Governance, $11(4), 6-8$ 
Kuo, L., Yeh, C. C., \& Yu, H. C. (2012). Disclosure of corporate social responsibility and environmental management: Evidence from China. Corporate Social Responsibility and Environmental Management, 19(5), 273-287.Available at: https://doi.org/10.1002/csr.274.

Lee, J., \& Jungbae Roh, J. (2012). Revisiting corporate reputation and firm performance link. Benchmarking: An International Journal, 19(4/5), 649-664.Available at: https://doi.org/10.1108/14635771211258061.

Long, H. C. (2015). The impact of market orientation and corporate social responsibility on firm performance: Evidence from Vietnam. Academy of Marketing Studies Journal, 19(1), 265-277.

Maqbool, S., \& Zameer, M. N. (2018). Corporate social responsibility and financial performance: An empirical analysis of Indian banks. Future Business Journal, 4(1), 84-93.

Miller, T. W. (2014). Modeling techniques in predictive analytics with Python and R: A guide to data science: FT Press.

Mittal, R., Sinha, N., \& Singh, A. (2008). An analysis of linkage between economic value added and corporate social responsibility. Management

Saeidi, S. P., Sofian, S., Saeidi, P., Saeidi, S. P., \& Saaeidi, S. A. (2015). How does corporate social responsibility contribute to firm financial performance? The mediating role of competitive advantage, reputation, and customer satisfaction. Journal of Business Research, 68(2), 341-350.Available at: https://doi.org/10.1016/j.jbusres.2014.06.024.

Santoso, A. H., \& Feliana, Y. K. (2014). The association between corporate social responsibility and corporate financial performance. Issues in Social and Environmental Accounting, 8(2), 82-103.

Skare, M., \& Golja, T. (2012). Corporate social responsibility and corporate financial performance-is there a link? Economic Research, 25(1), 215-242.

Smith, H. J. (2003). The shareholders vs. stakeholders debate. MIT Sloan Management Revierw, 44(4), 85-90.

Stuebs, M. T., \& Sun, L. (2011). Corporate social responsibility and firm reputation. Retrieved from: SSRN 1863343.

Sun, L. (2012). Further evidence on the association between corporate social responsibility and financial performance. International Journal of Law and Management, 56(6), 472-484.Available at: https://doi.org/10.1108/17542431211281954.

Theodoulidis, B., Diaz, D., Crotto, F., \& Rancati, E. (2017). Exploring corporate social responsibility and financial performance through stakeholder theory in the tourism industries. Tourism Management, 62, 173-188.Available at: https://doi.org/10.1016/j.tourman.2017.03.018.

Torugsa, N. A., O'Donohue, W., \& Hecker, R. (2013). Proactive CSR: An empirical analysis of the role of its economic, social and environmental dimensions on the association between capabilities and performance. Journal of Business Ethics, 115(2), 383-402.Available at: https://doi.org/10.1007/s10551-012-1405-4.

Trendafilova, S., Babiak, K., \& Heinze, K. (2013). Corporate social responsibility and environmental sustainability: Why professional sport is greening the playing field. Sport Management Reviere, 16(3), 298-313.Available at: https://doi.org/10.1016/j.smr.2012.12.006.

Vinzi, V. E., Chin, W. W., Henseler, J., \& Wang, H. (2010). Handbook of partial least squares (Vol. 201). Germany: Springer.

Wong, K. K. K. (2011). Book review: Handbook of partial least squares: Concepts, methods and applications.

Zhu, Y., Sun, L.-Y., \& Leung, A. S. (2014). Corporate social responsibility, firm reputation, and firm performance: The role of ethical leadership. Asia Pacific Journal of Management, 31(4), 925-947. 